\title{
Digital Payment Service in India - A Case Study of Unified Payment Interface
}

\author{
Mahesh A..$^{1,2 *}$, \& Ganesh Bhat ${ }^{3}$ \\ ${ }^{1}$ Research Scholar, CMC, Srinivas University, Mangaluru, India \\ ${ }^{2}$ Assistant Professor, Government First Grade College, Talakadu, Mysuru, India \\ OrcidID: 0000-0001-5196-9020; E-mail: mahi.mys62@gmail.com \\ ${ }^{3}$ Research Professor, CMC, Srinivas University, Mangaluru, India \\ OrcidID: 0000-0003-1950-8536; E-mail: ganbhatbvr@rediffmail.com
}

Area of the Paper: Business Management.

Type of the Paper: Research Case Study.

Type of Review: Peer Reviewed as per $|\mathrm{C}| \mathrm{O}|\mathrm{P}| \mathrm{E} \mid$ guidance.

Indexed In: OpenAIRE.

DOI: http://doi.org/10.5281/zenodo.5091207

Google Scholar Citation: IJCSBE

\section{How to Cite this Paper:}

Mahesh, A. \& Ganesh Bhat, (2021). Digital Payment Service in India - A Case Study of Unified Payment Interface. International Journal of Case Studies in Business, IT, and Education (IJCSBE), 5(1), 256-265. DOI: http://doi.org/10.5281/zenodo.5091207.

International Journal of Case Studies in Business, IT and Education (IJCSBE)

A Refereed International Journal of Srinivas University, India.

Crossref DOI : https://doi.org/10.47992/IJCSBE.2581.6942.0114

(C) With Authors.

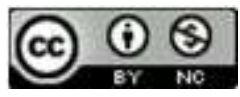

This work is licensed under a Creative Commons Attribution Non-Commercial 4.0 International License subject to proper citation to the publication source of the work.

Disclaimer: The scholarly papers as reviewed and published by the Srinivas Publications (S.P.), India are the views and opinions of their respective authors and are not the views or opinions of the S.P. The S.P. disclaims of any harm or loss caused due to the published content to any party. 


\title{
Digital Payment Service in India - A Case Study of Unified Payment Interface
}

\author{
Mahesh A. ${ }^{1,2 *}$ \& Ganesh Bhat ${ }^{3}$ \\ ${ }^{1}$ Research Scholar, CMC, Srinivas University, Mangaluru, India \\ ${ }^{2}$ Assistant Professor, Government First Grade College, Talakadu, Mysuru, India \\ OrcidID: 0000-0001-5196-9020; E-mail: mahi.mys62@gmail.com \\ ${ }^{3}$ Research Professor, CMC, Srinivas University, Mangaluru, India \\ OrcidID: 0000-0003-1950-8536; E-mail: ganbhatbvr@ rediffmail.com
}

\begin{abstract}
Purpose: The Indian Banking sector is striving hard to popularise digital payments and has gained momentum after demonetization and digital India initiatives. To facilitate digital payments, "National Payment Corporation of India (NPCI)" launched the "Unified Payment Interface (UPI)", which is an amazing, revamped, and cost-effective breakthrough for enabling digital payment services for all. Proliferation of smartphones, technological innovations, and effective internet communications has signified the usage of mobile payment facility for smartphone users, financial institutions and particularly the banks. To achieve paperless and cashless economy, Unified Payment Interface (UPI) is a potentially innovative way of transferring funds using a virtual payment address established by the National Payment Corporation of India (NPCI). Hence, it is needed to be assessed for its potential to contribute towards achievement of digital economy.
\end{abstract}

Design/Methodology/Approach: This paper is focused on understanding Unified Payment System's (UPI) growth and its progression in retail digital payment over the years. The study was carried out by exploring secondary data sources and by applying Strengths, Weaknesses, Opportunities, and Threats (SWOT) analysis format.

Finding/Result: UPI has shown remarkable growth in last couple of years due to customer's shift towards contactless payments over other methods. Study revealed that the growth of digital payments has increased significantly, especially in the retail payment sector on the UPI platform.

Originality value: This study examines UPI's position in the digital payment ecosystem, with an emphasis on identifying UPI's core strengths and growth prospects, as well as areas for future research to investigate India's complete e-payment ecosystem.

Paper type: A research case study on Digital Payment Service in India - A Case Study of Unified Payment Interface

Keywords: Digital Payment, Retail Payment, UPI, Digital Transactions, NPCI

\section{INTRODUCTION :}

India's banking system is now facing major structural reforms along with enhanced usage of Information and Communication Technology (ICT). It has transformed the banking system to a large measure from paper-mode to virtual mode and it facilitated speedy and secure fund transfer between bank accounts. Moreover, ICT enabled a variety of electronic payment mechanisms, commonly called digital payment services; within which UPI (Unified Payments Interface) has gained popularity. It is an e-payment system that allows users to perform a variety of financial transactions using a smartphone. Using a virtual payment address (VPA), one can send or receive money on the UPI platform without revealing bank account details. However, to execute UPI payment transactions, users must have a bank account and should get registered on the UPI app. In the case of business entities, a current account is required, just like a point of sale (PoS) computer. SBI Pay, Union Bank UPI App, Phonepe, G-Pay, BHIM Axispay, WhatsApp Pay are a few examples of UPI Apps. Presently all the banks and fintech players are operating Unified Payment Interface service through their respective mobile applications. 
The main intent of this paper is to figure out how the digital payment service by Unified Payment Interface (UPI) and where it fits into the digital ecosystem. It also examines the UPI's Strengths, Weaknesses, Opportunities, and Challenges. The paper starts with an overview of the Digital Payments and UPI status (i.e., the position of the UPI in digital payments with a critical analysis of UPI data). The emphasis then shifts to a SWOT analysis of UPI to analyse its Strengths, Weaknesses, Opportunities, and Threats in the current digital payment days. The final section of the paper focuses on identifying UPI's core strengths and growth prospects, as well as space for future research to explore the entire epayment ecosystem in India.

\section{OBJECTIVES :}

The primary goal of this case study is to look into the growth and prospects of the Unified Payment Interface (UPI). In this context, the following objectives are framed.

(1) To understand the Unified Payment Interface (UPI) system's growth.

(2) To assess UPI's position in the digital payment ecosystem.

(3) To know the progression of UPI in retail digital payments.

(4) To conduct a SWOT analysis of the UPI of NPCI.

\section{METHODOLOGY :}

This paper uses an exploratory research method to explore the required data from secondary sources such as published research works, RBI reports, government reports, etc. Based on collected data SWOT analysis has been applied to investigate key strengths, weaknesses, opportunities, and threats for growth and prospects of Unified Payment Interface in the digital payment industry.

\section{DIGITAL PAYMENTS :}

Digital payments refer to "payments made using digital instruments, such as mobile payment applications, mobile wallets, bitcoin or virtual currency coins, and other electronic payment methods". The use of technology in performing seamless financial transactions is termed digital Banking or FinTech Banking [1]". According to RBI "Digital Transaction means a payment transaction in a seamless system effected without the need for cash at least in one of the two legs, if not in both (i.e., payer or receiver or both). This includes transactions made through digital/electronic modes wherein both the originator and the beneficiary use digital/electronic medium to send or receive money"[2]. Due to the popularisation of digital payment among customers, the priorities of bank clients' have been shifted from a paper-based payment method of a monetary transaction to the electronic mode. Epayment systems in the retail business segment have made a significant contribution in promoting financial inclusion in a larger space. To capture new opportunities thrown by the digitised economy, businesses are conducting their commercial transactions utilising digital payment systems. However, there are problems that impede the adoption of digital payments that need to be addressed urgently [3]. India's expanding usage of digital payment in retail business transactions, retail digital payments witnessed a shift in the country's kindred with cash. This is seen by the rapid expansion of retail digital payments after initiating digital payment methods such as e-wallets, card payments, IMPS, UPI, etc. Cash still reigns supreme, but it is increasingly being viewed as a means of storing wealth as an economic asset rather than a means of making payments. The future of payments would be characterised by "speed, convenience, and competitiveness". In the eyes of the common man, cash is always seen as the king, whereas now digital is regarded as a god with the inception of the UPI payment system. "Immediate Payment Systems (IMPS) and Unified Payments Interface (UPI) are two quick payment systems that have boosted retail digital payments in India" [4]. India's e-payment ecosystem has grown rapidly since demonetisation. As per the RBI report, "during 2014 - 19 digital payments have shown compound annual growth rate (CAGR) of $61 \%$ in volume and $19 \%$ in value. Ongoing progress in new technology, innovative payment products, the emergence of inhibitory market players, and regulatory interventions have aided and accelerated the growth of the digital payment ecosystem" [5].

\section{UNIFIED PAYMENTS INTERFACE (UPI) :}

Under the provisions of 'The Payments and Settlements System Act, 2007' The Reserve Bank of India (RBI) and the Indian Banks Association (IBA) established the umbrella corporation - 'National 
Payments Corporation of India (NPCI)' to operate retail payments and settlements systems in India's payment ecosystem. To facilitate digital payments NPCI has developed an innovative payment instrument called 'Unified Payment Interface (UPI)'. It is a digital payment framework designed to perform various banking functions and retail business payments using any mobile application of member banks. "Peer to Peer (P2P)" collection requests, which can be arranged and charged according to need and convenience. Initially, UPI was operationalized as a pilot launch with 21 member banks. It was inaugurated on April 11, 2016, in Mumbai by then-RBI Governor Dr. Raghuram G Rajan [6]. Since August 25, 2016, participating banks have been uploading their UPI-enabled apps on the Google Play store. There are 227 Banks on UPI as of June 2021, with a monthly volume of 2,807.51 million transactions valuing Rs. 5,47,373.17 crore [7]. The UPI platform was upgraded to UPI 2.0 in 2018, increasing the single transaction limit from one lakh to two lakh rupees. Unified Payment Interface (UPI) is a tech-enabled payment arrangement allowing money to be transferred from one bank account to another in only a few clicks in no time. One can use any UPI client app, and a single app can be connected to multiple Bank accounts. Various payment methods like; Virtual Payment Address, Mobile Number, Account Number \& IFSC, AADHAR, and QR Code can be used to send or request money. The key drivers of UPI are SIASC - Simplicity, Innovation, Adoption, Security, and Cost [8].

\section{RETAIL PAYMENT :}

Retail transactions are referred to as transactions having low-value denominations and high in number. A variety of characteristics are exhibited by retail payment systems. They deal with numerous lowvalue individual payments in particular [9]. Retail payments differ from large-value transactions. To begin with, the term retail payment refers to a type of payment processing system that handles a significant number of low-value payments for the purchase and sale of goods \& services. They are used in a wider range of circumstances than interbank transactions, namely in-person payment using POS computers and payment over the internet. Next, in comparison to large-value transactions, retail payments use a wide range of payment instruments, including both paper-based and digital methods. Third, unlike large-value payments, which rely significantly on central bank-operated NEFT and RTGS systems, retail payments are typically handled by a variety of payment service providers such as banks, post offices, FinTech companies, and so on [10].

\section{POSITION OF UPI IN INDIA'S DIGITAL PAYMENT ECOSYSTEM :}

Digital Payment Ecosystem consists of the payer (initiator), receiver (accepter), acquirers (receiver's bank), and issuers (payer's bank). A digital payment ecosystem can be referred to as a system that connects all of these parties through a paperless mode of payment or fund transfers. As per the RBI database, India's digital payment ecosystem includes various digital payment instruments such as Banking cards (Debit/Credit Cards), Unstructured Supplementary Service Data (USSD), AADHAR enables payment system (AePS), Internet Banking (NEFT, IMPS, and RTGS), M - Wallets, Prepaid Payment Instruments (PPIs), and Unified Payment Interface (UPI). According to the most recent RBI data of May 2021, UPI is accounting for 58.47 percent of all digital payment transactions, totalling 2.53 billion transactions (Chart1). UPI was developed to facilitate payment systems in retail digital payment transactions, and it now accounts for more than half of the total transactions performed in the digital payment ecosystem. Due to the maximum ceiling restriction of Rs. 2,00,000 in the UPI payment system, NEFT, and RTGS continue to dominate in terms of volume, accounting for 89.29 percent of digital transactions during May 2021 amounting to 104.52 trillion rupees. (Chart 2). 


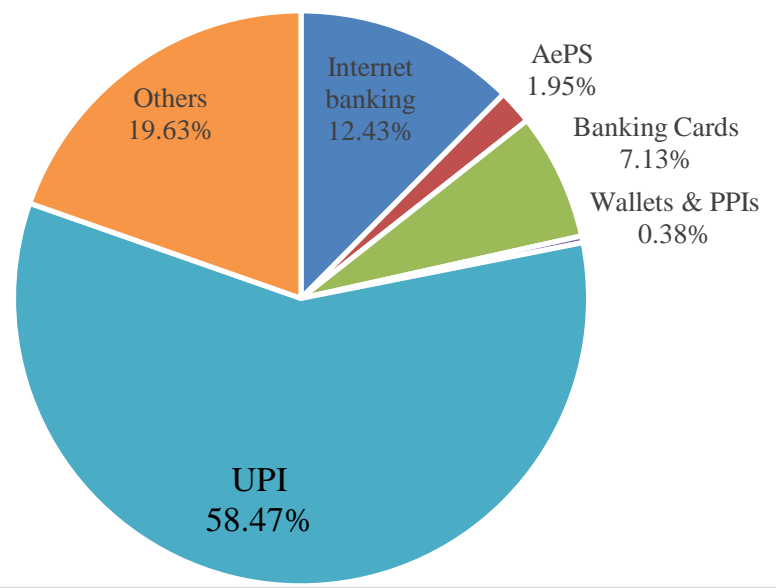

Fig. 1: Digital Payment and Settlement System data of May, 2021 (in terms of volume of transactions)

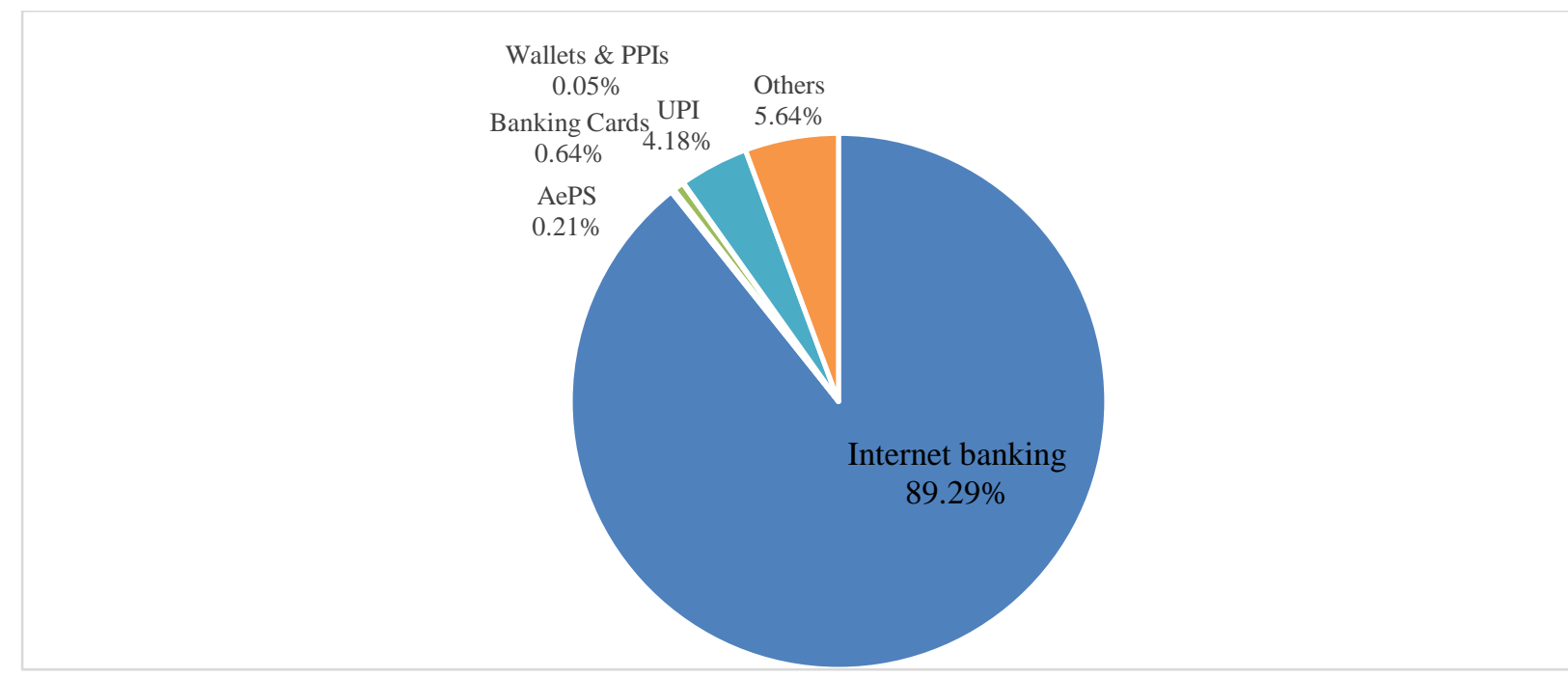

Fig. 2: Digital Payment and Settlement System data of May, 2021

Source: $R B I$ (in terms of value of transactions)

\section{UPI STATISTICS AT GLANCE (FROM 2016 TO 2021) :}

The UPI service was launched by NPCI in 2016 with the participation of 21 banks. During the financial year 2016 - 17, the contribution of UPI in digital payment services was only about 63 lakh transactions. At present, 2,100 crore transactions were performed on the UPI platform in the last 12 months, representing a staggering rise of nearly 900 crore transactions, which is showing $75 \%$ growth annually [11]. According to NPCI data, UPI railroad registered 2.73 billion transactions in March 2021, the most ever in a single month since it began operations in August 2016. RBI reported, due to the requirement of social distancing during the corona pandemic, contactless payments were preferred over cash payments, even though the value and volume of the latter were considerably down due to the slowdown in economic activity before the outbreak. The number of transactions on the UPI platform, as well as overall retail digital payment transactions, has risen exponentially, in value and size of transactions. The growth of UPI payments is shown in table 1 . 
Table 1: Growth of UPI from 2016 - 2021

\begin{tabular}{|c|c|c|c|}
\hline \multirow{2}{*}{ Month \& Year } & \multirow{2}{*}{$\begin{array}{l}\text { No. of Member } \\
\text { Banks }\end{array}$} & \multicolumn{2}{|c|}{ Transaction } \\
\hline & & Volume (in mn) & Value (in Cr.) \\
\hline Mar 2021 & 216 & $2,731.68$ & $5,04,886.44$ \\
\hline Mar 2020 & 148 & $1,246.84$ & $206,462.31$ \\
\hline Mar 2019 & 142 & 799.54 & $133,460.72$ \\
\hline Mar 2018 & 91 & 178.05 & $24,172.6$ \\
\hline Mar 2017 & 44 & 6.37 & $2,425.14$ \\
\hline Mar 2016 & 21 & 0.00 & 0.00 \\
\hline
\end{tabular}

\section{PROGRESSION OF UPI IN RETAIL DIGITAL PAYMENT :}

UPI is considered to be more user-friendly and safer than other online banking or digital payment methods. As a result, one can start using UPI to send and accept payments instantly. People are taking behoof [12] of the UPI payments which is encouraging businesses to adopt digital payment acceptance. The usage statistics of UPI platform for retail payments for last 5 year is shown in Table 2 below.

Table 2: Statistics of UPI on NPCI platform (from 2016 - 17 to 2020 - 21)

\begin{tabular}{|c|c|c|c|c|c|c|}
\hline \multirow[t]{2}{*}{ Year } & $\begin{array}{c}\text { Total } \\
\text { Financial } \\
\text { Txn } \\
\end{array}$ & $\begin{array}{c}\text { UPI } \\
\text { transaction }\end{array}$ & \multirow{2}{*}{$\begin{array}{c}\% \text { of } \\
\text { UPI to } \\
\text { Total }\end{array}$} & $\begin{array}{c}\text { Total } \\
\text { Financial } \\
\text { Txn } \\
\end{array}$ & $\begin{array}{c}\text { UPI } \\
\text { transaction }\end{array}$ & \multirow{2}{*}{$\begin{array}{c}\% \text { of } \\
\text { UPI to } \\
\text { Total }\end{array}$} \\
\hline & $\begin{array}{l}\text { Volume } \\
\text { (in Mn) }\end{array}$ & $\begin{array}{c}\text { Volume (in } \\
\text { Mn) }\end{array}$ & & $\begin{array}{c}\text { Value } \\
\text { (in Bn) }\end{array}$ & $\begin{array}{l}\text { Value } \\
\text { (in Bn) }\end{array}$ & \\
\hline $2016-17$ & $7,138.40$ & 17.86 & $0.25 \%$ & $96,626.07$ & 69.47 & $0.07 \%$ \\
\hline $2017-18$ & $9,857.60$ & 915.23 & $9.28 \%$ & $1,13,552.76$ & $1,098.32$ & $0.97 \%$ \\
\hline $2018-19$ & $16,806.25$ & $5,353.40$ & $31.85 \%$ & $1,36,719.23$ & $8,769.70$ & $6.41 \%$ \\
\hline $2019-20$ & $26,493.23$ & $12,518.62$ & $47.25 \%$ & $1,60,923.65$ & $21,317.30$ & $13.25 \%$ \\
\hline $2020-21$ & $37,512.73$ & $22,330.65$ & $59.53 \%$ & $1,65,529.97$ & $41,036.54$ & $24.79 \%$ \\
\hline
\end{tabular}

Source: https://www.npci.org.in/statistics

\section{SWOT ANALYSIS OF UNIFIED PAYMENT INTERFACE (UPI) :}

Individual and organisational effectiveness analysis aids in the recognition of numerous obstacles and the exploration of new growth opportunities. This can be done by employing SWOT analysis, TWOS analysis, Porter's Five Force Model, BCG Matrix, PESTLE (Political, Economic, Social, Technological, Legal and Environmental) analysis, and other techniques in use [13]. "SWOT analysis is an effective strategic tool that can be used efficiently and resourcefully to assess the strengths, weaknesses, opportunities, and threats of businesses" [14]. It is used to evaluate internal potentials and constraints, eventual external opportunities, and probable risks. Its main goal is to develop ways for creating a firm's unique business model, which better matches an organization's capital and capabilities with the demands of its operational environment by considering both positive and negative elements that affect the firm's success, both inside and outside the organisation [15][16]. 
The SWOT analysis of NPCI's UPI is as follows:

\subsection{Strengths:}

The strengths of UPI platform are as follows:

(1) Caters to Bottom of the Pyramid: UPI allows even the petty business person to start accepting digital payments without the need for a POS machine in India, where payment infrastructure is poor for accepting digital payments. UPI has eliminated the need for transacting parties to know the complicated payment credentials, and hence, making payments convenient and transparent for all parties involved. UPI operates on a safe, stable, and robust platform that includes numerous security features that make it more secure than any other payment system currently in use. Biometric authentication in UPI will not only make payments more reliable but will also mark a significant step forward in the integration of next-generation technology with current payment systems. UPI has the potential to be a major facilitator of financial inclusion in India, enabling a large portion of the population to engage in the digital economy [17].

(2) Corruption Deterrent: In developing countries, digital financial transactions contribute to a lessening of corruption and reduction in the contagion of the parallel economy [18].

(3) Simplified Payment Mechanism: It enables to use of the mobile phone as the primary payment mechanism for all transactions, including P2P, P2B, and B2P.

(4) Pay \& Collect: Users can use their mobile phones to "pay" (push) and "collect" (pull) money from others.

(5) Multiple payment options: Multiple identifiers, such as customised Virtual Payment Address (VPA), 12-digit AADHAR Number allotted by Unique Identification Authority of India (UIDAI) or Bank Account Number, and Indian Financial System Code (IFSC) can be used to make payments.

(6) Secure sensitive information: Users of UPI can make payments through a Virtual Payment Address without revealing account credentials.

(7) Notified of Future Payment: Ability to send collect requests to someone with a "pay by" deadline (i.e., P2P or B2B). It sends a "snooze" notification to the payer, allowing them to pay before the expiration date. It does not hold money in the account until the consumer has paid it.

(8) Multiple Virtual Payment Address (VPA) across PSPs: In UPI 2.0, users can add numerous bank accounts, including overdraft accounts, and create an unlimited number of Virtual Payment Addresses via mobile apps offered by PSPs (Payment Service Providers).

(9) Open usage: Ability to use a completely interoperable system across all payment system players without relying on closed networks and silos.

(10) Bill Payment: Payment of utility bills on a single platform through Bharath Bill Pay service (BBPS) available in UPI.

10.2. Weaknesses:

The NPCI's UPI platform has the following weaknesses:

(1) Delayed Transaction: Payment settlement may be delayed due to technical glitzes, leaving a transaction to be interrupted.

(2) Irritation on Double verification: Two-factor authentication like mobile and PIN verification may irritate the users.

(3) Transaction limit: The maximum amount that may be transferred is Rs.2,00,000. As a result, it is limited to the retail payment segment [19].

(4) Requirement of cooling period: Payments done through means other than VPA, such as Account Number and IFSC, are subject to the same cooling period as NEFT/RTGS transactions.

(5) Cybercrimes: The greatest downside of using UPI is that the banks are not assisting customers with security issues. The majority of fraudsters nowadays ask for money to be transferred via UPI. Customers should be careful enough while performing transactions over UPI [20].

\subsection{Opportunities:}

The opportunities available for UPI are: 
(1) Strong Banking Network: A strong Banking network, and the launch of Digital India especially after demonetization, propelled the country toward a cashless economy.

(2) Growth in Retail Digital Payment: During FY 2020-21, the retail payment segment has seen rapid growth in the use of digital payment services, with transaction volume doubling from 12.5 billion to 22.3 billion and value double from Rs 21.3 trillion to Rs. 41 trillion.

(3) Internet Penetration: A large portion of the country's population lives in semi-urban and rural areas. The prospective consumer base in these geographical areas will rise as the use of the internet and mobile phones grow.

(4) Widening the scope of services: Initially, UPI was used for fund transfers between bank accounts. Presently it is providing a wide range of digital payment services such as bill payments, investments, insurance, donations, handling overdraft accounts, one-time payment mandate, etc.

(5) PMJDY: Prime Ministers Jhan Dhan Yojana (PMJDY) programme as a financial inclusion strategy related to opening bank account among poorer households particularly those engaged in casual labour activities and illiterate [21]. This enlarged the base of account holders.

(6) Cash-lite economy: RBI's Vision 2021 aims at building a strong digital payment ecosystem by shifting to a cash-lite economy [22]. The government wants to reduce the use of real currency by implementing easy digital payment channels.

(7) Zero Merchant Discount Rate (MDR): To encourage the use of digital payments, the government has exempted UPI and RuPay-based payments from the Merchant Discount Rate. This has increased the use of UPI and RuPay in making payments on e-payment gateways.

10.4. Threats:

The following are the obstacles that UPI must overcome:

(1) Awareness: UPI usage awareness creation among the rural and illiterate population of the country is most challenging.

(2) Cash is the King: Even though many e-commerce sites have adopted digital payment methods, consumers still prefer to pay with cash. This trend is linked to concerns about cybersecurity in digital transactions [23].

(3) Emergence of FinTech players: Strengthening of the traditional Banking system to compete with tech generation companies i.e., FinTech Players.

(4) Grievance redressal: Pathetic Grievance redressal system for transactions performed over UPI platform.

(5) Tax on UPI service: Levy of Tax/GST on UPI payment service in future days may demotivate usage of UPI platform. The regulators need to be cautious in this regard.

(6) Restoration of Merchant Discount Rate: Users may shift to cash payments in retail payments after the government reinstates the exempted MDR fee on UPI payments.

\section{FINDINGS AND SUGGESTIONS :}

Credit cards, Debit cards, Internet Banking (NEFT/IMPS/RTGS), Mobile banking, Digi-wallets, Aadhar enables Payment Service (AePS), and the Unified Payments Interface (UPI) are the different options available for digital payments and transfers. UPI offers superior advantages through services such as instant payment using QR code, payment of various fees, fund transfers between bank accounts $\&$ wallets, donations, buying \& renewal of insurance, payment of utility bills through Bharath BillPay, etc. With UPI 2.0 NPCI has allowed users to add their overdraft accounts, one-time payment mandate with enhanced security measures. It has the unique advantage of 'No need to add a beneficiary'. It allows users to make transactions through a Virtual Payment Address (VPA) without revealing technical credentials such as account number, IFS Code, Name, etc. Even though UPI faces cyber threats and technological challenges, it has a lot of opportunities in today's digital world due to its key strengths SIASC - Simplicity, Innovation, Adoption, Security, and Cost-effective. "Most people are rushing to cashless transactions because they have little cash on hand and an impending cash crunch" [24]. The growth of users of smartphones and internet penetration facilitated in such situations to adopting for digital payment service [25]. Due to the covid pandemic outbreak, people are preferring contactless payment methods over other payment options [26]. Because of the widespread use of smartphones and related apps, a mobile payment system is an enticing alternative that has recently 
blossomed. Expected performance, social impact, pricing rate, safety, and data privacy are considered to be important factors influencing the adoption of the mobile payment system [28][29][28]. Users benefit from the convenience and speed of digital transactions through UPI. Because it is easier to access via smartphone than other digital payment options, it is gaining in popularity, especially in the retail payment industry. Regulators may use UPI to achieve the country's maximum financial inclusion. In the future, if regulators want to levy a service tax on UPI, they are to be careful and focus on upgrading the existing banking network to make it easier for FinTech businesses to provide payment services. To resolve consumer grievances, PSPs must build effective grievance redressal systems. The main disadvantage of UPI is that it can only be used by people who have Bank accounts. It is deafeningly silent among the unbanked rural population. User's attitudes toward UPI and other e-Payment alternatives could be studied in the future, and the results could be analysed using systematic behaviour models.

\section{REFERENCES :}

[1] Sardana, V., \& Singhania, S. (2018). Digital Technology in the Realm of Banking: A Review of Literature. International Journal of Research in Finance and Management, 1(2), 28-32. https://www.researchgate.net/publication/329514279

[2] Ombudsman Scheme for Digital Transactions, 2019 Retrieved May 2, 2021, from https://rbidocs.rbi.org.in/rdocs/Content/PDFs/OSDT31012019.pdf

[3] Raharja, S. J., Sutarjo, Muhyi, H. A., \& Herawaty, T. (2020). Digital Payment as an Enabler for Business Opportunities: A Go-Pay Case Study. Review of Integrative Business and Economics Research, 9(1), 319-329. http://buscompress.com/journal-home.html

[4] Assessment of the progress of digitisation from cash to electronic (2020), Retrieved on May 2, 2021, from https://www.rbi.org.in/Scripts/PublicationsView.aspx?id=19417

[5] Evolving business models in the payments industry (November 2020) Retrieved on May 2, 2021, from https://www.pwc.in/consulting/financial-services/fintech/dp/evolving-business-models-inthe-payments-industry.html

[6] Raghuram Rajan gives a parting gift, turns your smartphone into a bank with UPI (2016), $\begin{array}{lllll}\text { Retrieved on } & \text { May 2, from }\end{array}$ https://economictimes.indiatimes.com/industry/Banking/finance/Banking/raghuram-rajangives-a-parting-gift-turns-your-smartphone-into-a-Bank-withupi/articleshow/53857902.cms?from $=\mathrm{mdr}$

[7] UPI Product Statistics (2021), Retrieved on June 18, 2021, from https://www.npci.org.in/whatwe-do/upi/product-statistics

[8] UNIFIED PAYMENT INTERFACE API and Technology Specifications (February 2015) Retrieved on May 1, 2021, from https://www.mygov.in/digidhan/pages/pdf/sbi/NPCI\%20Unified\%20Payment\%20Interface.pdf

[9] Viviana Alfonso, Alexandre Tombini, F. Z. (2020). Retail payments in Latin America and the Caribbean: present and future. BIS Quarterly Review, December, 71-87.

[10] Committee on Payment and Settlement Systems. (2012). Innovations in retail payments : Report of the Working Group on Innovations in Retail Payments (2012th ed., Issue May). Bank for International Settlements.

[11] Why digital payment is a public good (March 2021), Retrieved on May 2, 2021, from https://www.thehindubusinessline.com/opinion/why-digital-payment-is-a-publicgood/article34093572.ece

[12] Godambe, A. C. (2020). Unified Payments Interface (UPI) - Advantages and Challenges. International Research Journal of Engineering and Technology (IRJET), 07(12), 971-973. 
[13] Aithal, P. S., Shailashree, V. T., Suresh Kumar, P. M. (2015). A New ABCD Technique to Analyze Business Models \& Concepts. International Journal of Management, IT and Engineering, 5(4), 409-423.

[14] Benzaghta, M. A., Elwalda, A., Mousa, M., Erkan, I., \& Rahman, M. (2021). SWOT analysis applications: An integrative literature review. Journal of Global Business Insights, 6(1), 55-73. https://doi.org/10.5038/2640-6489.6.1.1148

[15] Teoli D, S. T. (2019). SWOT Analysis. Treasure Island (FL): StatPearls Publishing

[16] Aithal, P. S., Suresh Kumar, P. M. (2015). Applying SWOC Analysis to An Institution of Higher Education. International Journal of Management, IT and Engineering, 5(7), 231-247.

[17] Gochhwal, R. (2017). Unified Payment Interface-An Advancement in Payment Systems. American Journal of Industrial and Business Management, 07(10), 1174-1191.

[18] Tenace Kwaku Setor, P. K. Senyo, A. A. (2021). Do digital payment transactions reduce corruption? Evidence from developing countries. Telematics and Informatics, 60(01), 6-14.

[19] UPI FAQs (2021), Retrieved on May 5, 2021, from https://www.npci.org.in/what-wedo/upi/faqs\#: :text=At\%20present\%2C\%20the\%20upper\%20limit,1\%20Lakh.

[20] What is the Impact of UPI on e-wallets?, Retrieved on May 5, 2021, from https://blog.finology.in/economy/what-are-the-impacts-of-upi-on-e-wallets

[21] Dutta, S., \& Mehta, B. S. (2021). Banking the unbanked: The performance and impact of pradhan mantri jan dhan yojana (PMJDY) schemes on poor households in Bihar. IASSI-Quarterly, 40(1), $5-28$.

[22] RBI Vision 2019-2021: The way forward (August 2019), Retrieved on May 30, 2021, from https://www.pwc.in/assets/pdfs/consulting/financial-services/fintech/point-of-view/povdownloads/rbi-vision-2019-2021.pdf

[23] Digital Payments in India: Challenges and Opportunities (July 10, 2019), Retrieved on May 5, 2021) https://www.entrepreneur.com/article/336559 (accessed on May 5, 2021)

[24] Ramya, N., Sivasakthi, D., \& Nandhini, M. (2017). Cashless Transaction: Modes, Advantages, and Disadvantages. International Journal of Applied Research, 3(1), 122-125. www.allresearchjournal.com

[25] Htay, S. N. N., Salman, S. A., \& Meera, A. K. M. (2013). Let's Move to" Universal Corporate Governance Theory". Journal of Internet Banking and Commerce, 18(2), 1-10.

[26] Reserve Bank of India. (2020). Report on Trend and Progress of Banking in India 2019-20. In Dr. Snehal S. Herwadkar for the Reserve Bank of India, Mumbai 400001 (Vol. 53, Issue 9).

[27] Pesce, M., Shi, C., Critto, A., Wang, X., \& Marcomini, A. (2018). SWOT analysis of the application of international standard ISO 14001 in the Chinese context. A case study of Guangdong Province. Sustainability (Switzerland), 10(9), 1-19. https://doi.org/10.3390/su10093196

[28] Alkhowaiter, W. A. (2020). Digital payment and banking adoption research in Gulf countries: A systematic literature review. International Journal of Information Management, 53(102102), 117. https://doi.org/10.1016/j.ijinfomgt.2020.102102

[29] Al-Okaily, M., Lutfi, A., Alsaad, A., Taamneh, A., \& Alsyouf, A. (2020). The Determinants of Digital Payment Systems' Acceptance under Cultural Orientation Differences: The Case of Uncertainty Avoidance. Technology in Society, 63(September), 1-15. https://doi.org/10.1016/j.techsoc.2020.101367 